\title{
Secretion of Glucagon from the
}

\section{Isolated, Perfused Canine Pancreas}

\author{
JOHAN IVERSEN \\ From the Second University Clinic of Internal Medicine, Kommunehospitalet, \\ Århus, Denmark
}

A в S T R A C T Using the isolated, perfused canine pancreas preparation, previously described, the interrelationship of the secretion of pancreatic glucagon and insulin was studied after stimulation with glucose, gastrointestinal hormones, and the amino acid arginine.

The results confirm the concept that pancreatic glucagon is a hormone of "glucose need" and suggest that it may be important in a moment to moment control of glucoregulation. The secretion of pancreatic glucagon was stimulated after infusion of gastrin, pancreozymin, and arginine, while no increase was associated with secretin infusion. The magnitude of the increase was closely related to the glucose concentration present in the perfusion medium, being higher and more pronounced during perfusion with low concentrations of glucose $(25 \mathrm{mg} / 100 \mathrm{ml}$ or $50 \mathrm{mg} / 100 \mathrm{ml})$.

Stimulation of insulin secretion was seen after glucose, gastrin, pancreozymin, secretin, and arginine. The magnitude of the increase was again closely related to the glucose concentration present, this time being higher and more pronounced during perfusion with high glucose concentrations $(150 \mathrm{mg} / 100 \mathrm{ml})$.

Secretion of both pancreatic hormones always followed a biphasic response pattern after the stimuli mentioned, similar to the characteristic release pattern previously described for insulin after an increment in glucose concentration.

In order to elucidate whether endogenous pancreatic glucagon possesses an insulinogenic action, as it has been shown to be the case with the administration of exogenous pancreatic glucagon, the time interrelationship of the secretion of pancreatic glucagon and insulin was investigated by determining the initial rise of the hormones after stimulation with gastrin, pancreozymin, and arginine. The rise of glucagon and insulin occurred

This work was presented in part at the 7th Congress of the International Diabetes Federation, 26 August 1970, Buenos Aires, Argentina.

Received for publication 29 December 1970. simultaneously, i.e. inside a $10 \mathrm{sec}$ period. This does not, however, exclude with certainty an insulinogenic role of pancreatic glucagon.

\section{INTRODUCTION}

Studies on the physiological role of pancreatic glucagon have been carried out by determining the glucagon concentration in peripheral plasma in humans after administration of various substances (1-3). The interpretations of the results of immunoassayable plasma-glucagon determinations, however, have been difficult and questionable for a number of reasons.

First of all, any response observed in vivo must be the result of the effect of the substance itself as well as a number of known and unknown counterregulatory mechanisms of nervous and humoral origin. Second, it is implied that pancreatic glucagon is diluted in peripheral blood to concentrations near the limits of the sensitivity of most immunoassays. Third, more or less specific antibodies must be employed to distinguish these low values of pancreatic glucagon from other immunoreactive substances in plasma (3-4). Catheterization studies on the pancreaticoduodenal vein glucagon in dog (5-10) have yielded important information on the secretion of pancreatic glucagon. Even such experiments, however, give results which in some cases may be difficult to interpret mainly because the experimental set-up precludes control and measurement of the pancreatic blood flow, and because up to $90 \%$ of the glucagon immunoreactivity estimated in the pancreaticoduodenal vein with unspecific antisera consists of other substances (gastrointestinal factors, proteins, etc.) $(4,11,12)$. This renders difficult the detection of small acute (though possibly physiologically important) changes in the secretion of pancreatic glucagon.

In the present study, the secretion of pancreatic glucagon has been investigated using the effluent from the isolated, perfused canine pancreas. The purpose of the study was to provide in vitro information on the re- 


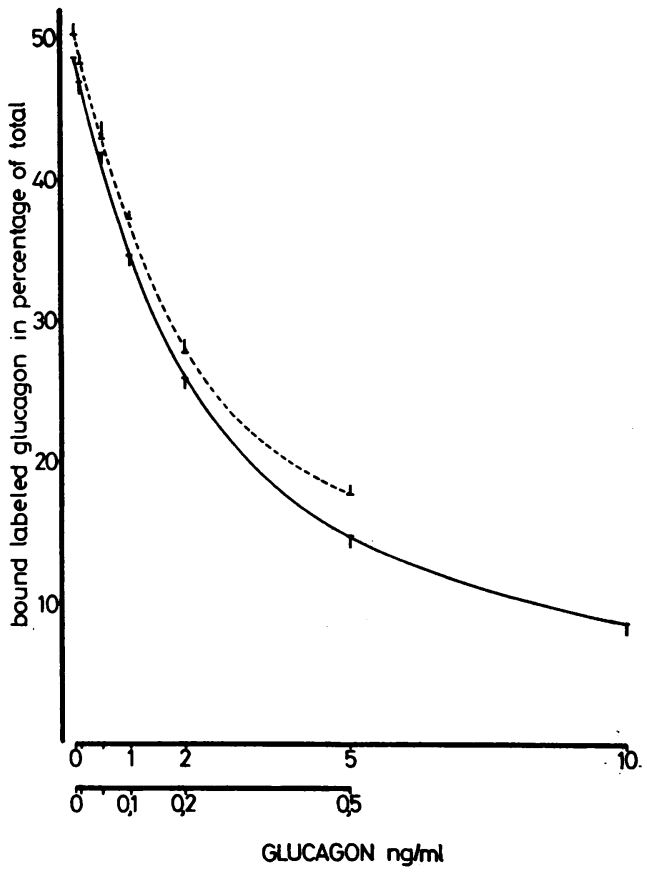

FigURE 1 Glucagon standard curves, using $50 \mu$ l samples for values in the range from 0 to $10 \mathrm{ng} / \mathrm{ml}$ (unbroken line) and $500 \mu \mathrm{l}$ samples for values in the range from 0 to 0.5 $\mathrm{ng} / \mathrm{ml}$. Mean values of three determinations $\pm_{\mathrm{SEM}}$.

sponse pattern and the time interrelationship of the secretion of pancreatic glucagon and insulin after glucose, the intestinal hormones gastrin, pancreozymin, and secretin and the amino acid arginine.

\section{METHODS}

Fasting male dogs weighing $20-30 \mathrm{~kg}$ were anesthetized with thiopentone, intubated, and ventilated with positive pressure respiration, using $\mathrm{O}_{2}$ and $\mathrm{NO}_{2}$ in a ratio of $1: 3$.

The operative procedure was carried out and the perfusion system established as described in detail in a previous publication (13). The preparation consists of the pancreas and the proximal $10 \mathrm{~cm}$ of the attached duodenum. The celiac artery and the portal vein are catheterized. The pancreas is perfused without recirculation with a synthetic medium, consisting of a Krebs-Ringer buffer modified to the electrolyte concentrations found in dog plasma, containing $4 \%$ dextran (commercial Macrodex $\mathrm{Mw} 70,000$ Pharmacia, Uppsala, Sweden), $0.2 \%$ bovine albumin (Ortho Pharmaceutical Corporation, Raritan, N. J.), fumarate, pyruvate, and glutamate each at a concentration of $5 \mathrm{~mm}$, porcine insulin (Actrapid, Novo A/S, Copenhagen, Denmark) 20-25 $\mu \mathrm{U} / \mathrm{ml}$, and a glucose concentration of $25 \mathrm{mg} / 100 \mathrm{ml}$. The perfusate is oxygenated by a roller screen oxygenator in an atmosphere of $94.4 \% \quad \mathrm{O}_{2}$ and $5.6 \% \quad \mathrm{CO}_{2}$ and heated to a temperature of $37 \pm 1{ }^{\circ} \mathrm{C}$ by use of low wattage heaters with a large surface area. The perfusate is pumped through the gland by means of a roller pump. A constant flow rate of $18-20 \mathrm{ml} / \mathrm{min}$ is achieved with a perfusion pressure which settles between $30-40 \mathrm{~mm} \mathrm{Hg}$ within 5-10 min after start of the perfusion; both parameters are constant throughoutthe experiment. Leakage from the preparation is negligible, most often it is zero. Edema never occurs during the experimental period of $4-6 \mathrm{hr}$.

To assess the viability of the organ, glucose uptake, oxygen consumption (for details, see (13)), potassium concentration, and lactate production were measured. They were constant throughout the experiment and gave some indication of the status of the preparation as a whole. The definitive assessment of the islet function was made by observing the insulin response to glucose at the end of each experiment.

Biochemical methods. Glucagon and insulin were measured by radioimmunoassay using the wick-chromatography method described by $\emptyset$ rskov $(14,15)$. This single antibody assay is well suited as it allows for an easy determination of "incubation" damage. Such an estimation is theoretically especially important on the effluent from an organ which produces proteolytic enzymes. There was no interference in the immunological system of either the $0.2 \%$ albumin or the $4 \%$ Macrodex concentration. Still, the precaution was taken to use the perfusion buffer as solvent for the standard to create identical media.

The system for glucagon measurement employs labeled beef glucagon prepared according to Hunter and Greenwood (16). After addition of bovine albumin and Trasylol $(10,000 \mathrm{KIU} / \mathrm{ml} \mathrm{Fa}$. Bayer, Leverkusen, Germany) to produce final concentrations of $1 \%$ and $500 \mathrm{KIU} / \mathrm{ml}$, the crude iodination product was dialyzed (VisKing tube 28/ 48, Union Carbide Corp, New York) against an anion exchange resin (Amberlite IRA 401, Rohm and Haas Co, Philadelphia) at $4^{\circ} \mathrm{C}$ for $3 / 4 \mathrm{hr} \times 2$. The glucagon- ${ }^{125} \mathrm{I}$ was purified by means of a column of Sephadex (Pharmacia, Uppsala, Sweden) (mixture of G-50 fine and G-75 superfine in the ratio $5: 1$ ) using as solvent a phosphate buffer $(0.04 \mathrm{~m}, \mathrm{pH} 8.0)$ containing merthiolate $(0.6 \mathrm{M})$, bovine albumin (10 g/liter), and Trasylol $(500 \mathrm{KIU} / \mathrm{ml})$. After purification, the glucagon- ${ }^{125} \mathrm{I}$ contained about $1-3 \%$ of damaged material, estimated as nonspecific migration of the labeled hormone. Antiglucagon was produced by immunization of rabbits with twice recrystallized porcine glucagon (Novo A/S, Copenhagen, Denmark). Beef glucagon was used as a standard as canine standards were not available. However, canine pancreatic glucagon appears to be immunologically similar to beef glucagon (17). Trasylol was added to the labeled hormone in a concentration of 500 $\mathrm{KIU} / \mathrm{ml}$ to protect glucagon against degradation. $50 \mu 1$ standards (triplicate) or samples (single determinations of the 400-600 samples) were pipetted into $10 \times 50 \mathrm{~mm}$ tubes. For more exact determination of extremely low glucagon values $500 \mu \mathrm{l}$ standards or samples were employed (see Fig. 1). $100 \mu 1$ porcine glucagon- ${ }^{125} \mathrm{I}$ and $100 \mu 1$ antibeef-glucagon serum were added. After $24 \mathrm{hr}$ of incubation at $4^{\circ} \mathrm{C}$ a $200 \mu \mathrm{l}$ sample of the mixture was applied to the wick (Whatman 3 MM). When $500 \mu 1$ standards or sample were used the incubation period was prolonged to $48 \mathrm{hr}$, and a $230 \mu \mathrm{l}$ sample of the mixture was applied to the wick. Every 12th tube contained $100 \mu \mathrm{l}$ buffer instead of anti-glucagon serum for check and calculation of damage. With the more sensitive assay it is possible to distinguish differences in glucagon concentrations of $10 \mathrm{pg} / \mathrm{ml}$ with $95 \%$ confidence $(0 \mathrm{pg} / \mathrm{ml}$ standards, $\mathrm{n}=6,10 \mathrm{pg} / \mathrm{ml}$ standards, $\mathrm{n}=3$ ).

The antiglucagon employed does not distinguish between glucagon from the gut (GLI) and glucagon from the pancreas. However, the present preparation consists only of the pancreas and the proximal $10 \mathrm{~cm}$ of the attached duodenum 
which contains very little glucagon-like immunoreactivity $(6,18,19)$.

A slight modification was introduced in the system employed for insulin measurements. The modifications are as follows: (a) Porcine insulin standards (porcine insulin being structurally and immunologically identical to canine insulin) were prepared in the perfusion buffer, containing $0.2 \%$ bovine albumin (Ortho) and 4\% dextran (Macrodex). 15 $\mu$ l standards (triplicate) or samples (single determinations) were pipetted into $10 \times 50 \mathrm{~mm}$ tubes. In experiments where high insulin concentrations ( $\geqq 1000 \mu \mathrm{U} / \mathrm{ml}$ ) were encountered, a modified assay was set up with $5 \mu \mathrm{l}$ standards or samples. (b) $100 \mu \mathrm{l}$ human insulin- ${ }^{125} \mathrm{I}$ and (c) $100 \mu \mathrm{l}$ antihuman insulin serum were added, and after $24 \mathrm{hr}$ of incubation at $4^{\circ} \mathrm{C}$, a $180 \mu \mathrm{l}$ sample of the mixture was applied to the wick. As in the glucagon immunoassay check and calculation of "incubation" damage were carried out by substituting anti-insulin serum with buffer in every 12th tube.

No proteolytic enzymes escaped from the perfused pancreas. This was apparent from the fact that perfusate incubation damage was identical to that calculated for the standard media both estimated chromatographically as the nonspecific migration of labeled hormone with plasma proteins and immunologically as the maximum binding of labeled hormone in the presence of an antibody excess. The values of nonspecific migration have varied between 4 and
$12 \%$ depending upon the storage time of the labeled hormone. Maximum binding of the labeled hormone in the presence of an antibody excess corrected for nonspecific migration varied between $82-90 \%$ in the glucagon assay, depending upon the quality of the labeled hormone. For the insulin assay values of $92-96 \%$ were obtained.

Glucose was measured using a glucose oxidase method (Glox, Kabi reagents, Stockholm, Sweden). There was no interference from the high dextran concentrations in these glucose determinations.

Experimental procedure. Samples were taken every minute from the influx and the efflux. To protect glucagon against proteolytic degradation, $250 \mu 1$ EDTA (30\%) was added to the tubes collecting the efflux, resulting in a final concentration of $4 \mathrm{mg} / \mathrm{ml}$. The samples were transferred within $\frac{1}{2} \mathrm{hr}$ to a freezer providing a temperature of $-20^{\circ} \mathrm{C}$.

The substances to be examined were added to the perfusate by means of constant infusion syringes, containing appropriate high concentrations. The infusion pumps were adjusted to speeds which gave from 0.1 to $0.56 \mathrm{ml} / \mathrm{min}$ to the flow which was $18-20 \mathrm{ml} / \mathrm{min}$. When any of the hormones was administered it was dissolved in the perfusion buffer immediately before use.

Synthetic human gastrin I was obtained from ICI (Imperial Chemical Industries Limited, Pharmaceuticals Division, Cheshire, England). Porcine pancreozymin, containing

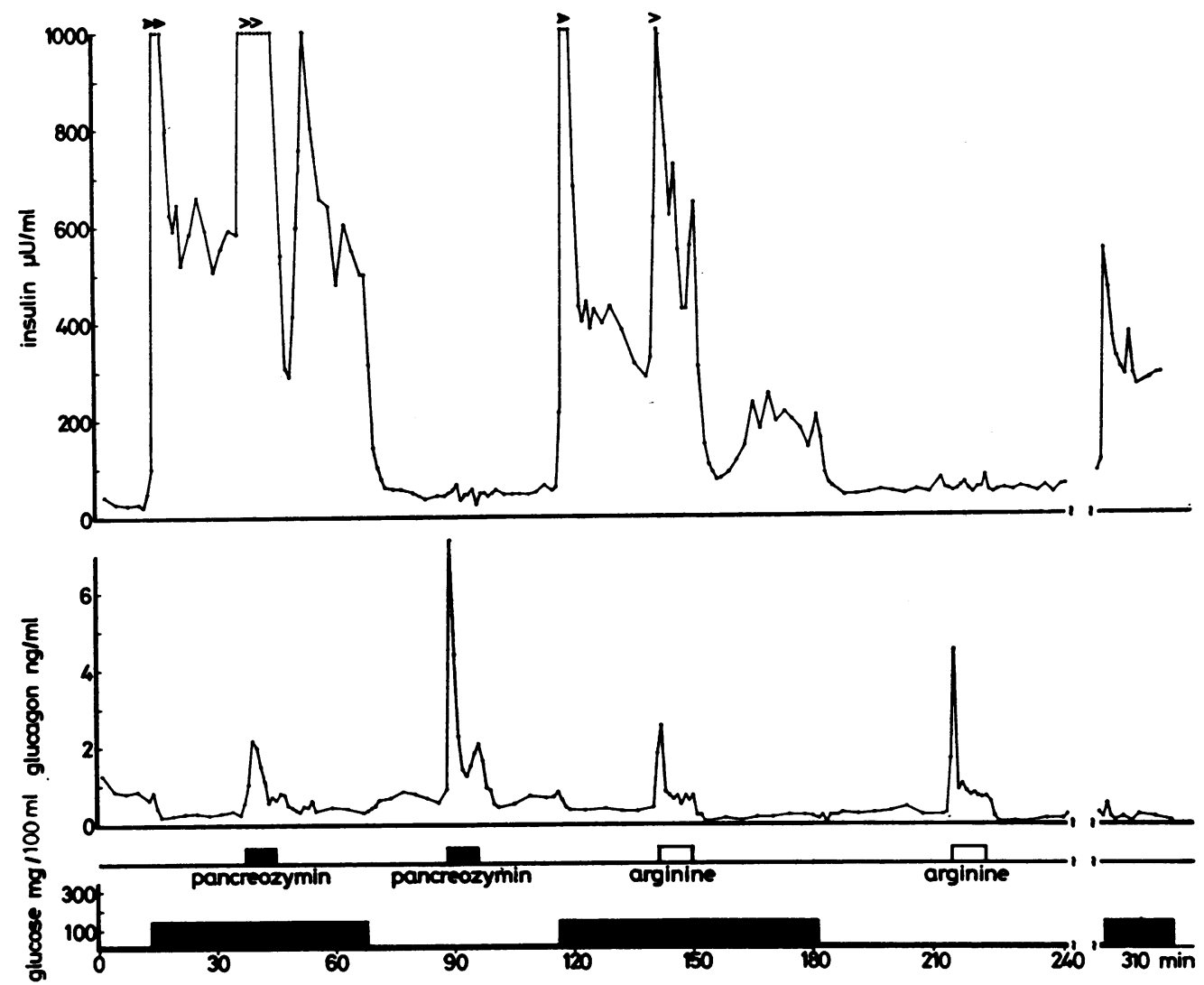

FIGURE 2 Effect of pancreozymin and arginine on the secretion of pancreatic glucagon and insulin during perfusion with a glucose concentration of $25 \mathrm{mg} / 100 \mathrm{ml}$ and $150 \mathrm{mg} / 100 \mathrm{ml}$. $\longrightarrow$, peak value $1600 \mu \mathrm{U} / \mathrm{ml} ; \rightarrow$, peak value $1670 \mu \mathrm{U} / \mathrm{ml} ;>>, 3480,2900,1585,1050,1040$, $1150,1110,1270 \mu \mathrm{U} / \mathrm{ml} ;>, 2180 \mu \mathrm{U} / \mathrm{ml}$. 

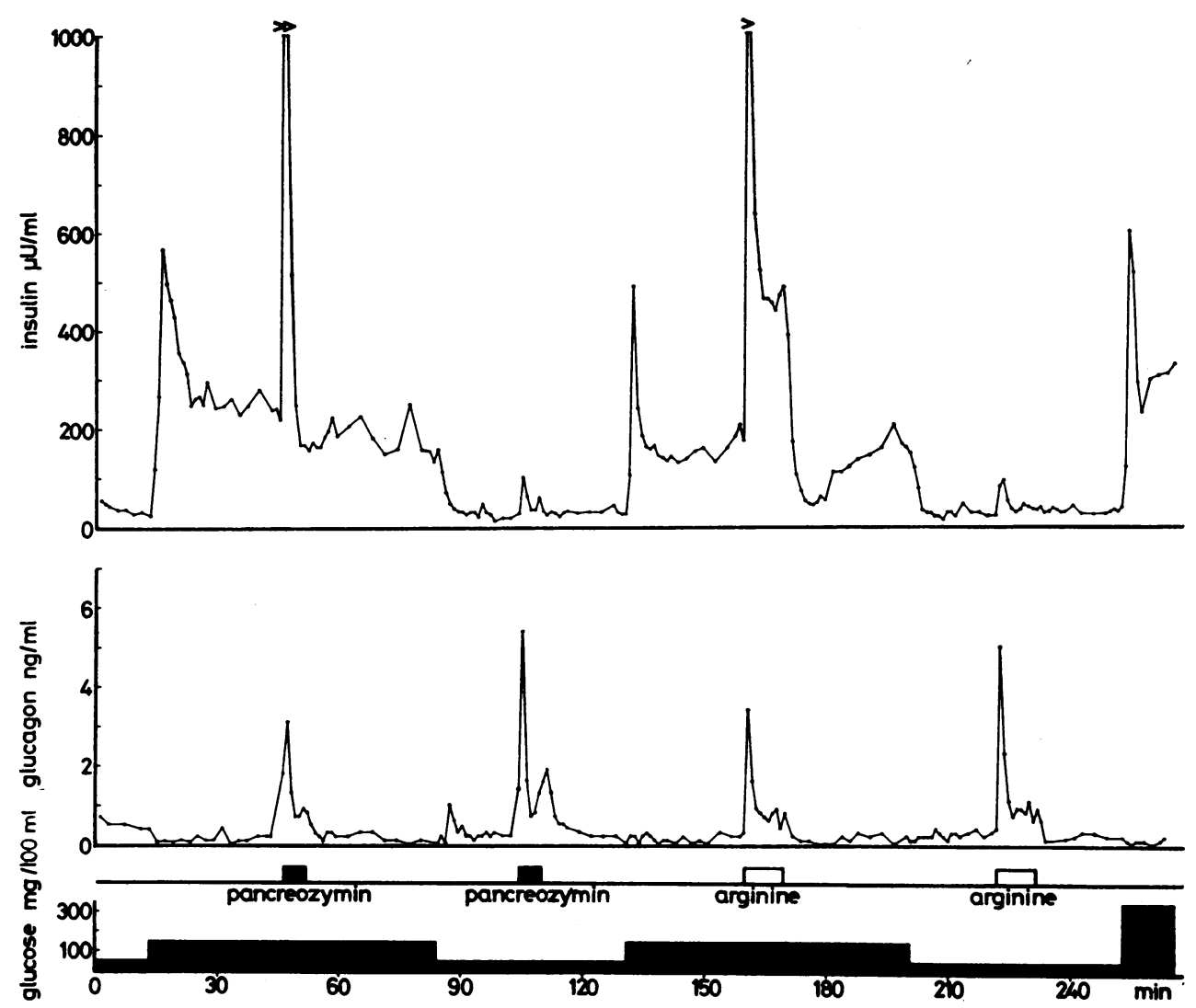

FIGURE 3 Effect of pancreozymin and arginine on the secretion of pancreatic glucagon and insulin during perfusion with a glucose concentration of $50 \mathrm{mg} / 100 \mathrm{ml}$ and $150 \mathrm{mg} / 100 \mathrm{ml}$. $>, 1088,1664 \mu \mathrm{U} / \mathrm{ml} ;>>, 1152,1040 \mu \mathrm{U} / \mathrm{ml}$.

approximately 12.5 Crick-Harper-Raper ${ }^{1}$ units $/ \mu \mathrm{g}$ and porcine secretin, containing 20 clinical units/ $\mu \mathrm{g}$ were prepared and assayed by Professor E. Jorpes and Dr. V. Mutt of Karolinska Instituttet, Stockholm. During stimulation with gastrin, pancreozymin, and secretin, samples from the influx were measured for glucagon and insulin in order to correct for impurities of the gut-hormone preparations used, and also because the presence of glucagon-like immunoreactivity might play a role in the rise in insulin secretion observed. None of the intestinal hormones, in the concentrations in which they were used in these experiments, contained glucagon-like immunoreactivity which could be detected by our glucagon immunoassay. Likewise, no insulin immunoreactivity was detectable.

Arginine was given as L-arginine hydrochloride. There was no effect upon the standard immunoassay curve for glucagon and insulin by arginine.

The pancreas was perfused for an equilibration period of $30-40 \mathrm{~min}$ with a glucose concentration of $25 \mathrm{mg} / 100 \mathrm{ml}$ or $50 \mathrm{mg} / 100 \mathrm{ml}$.

The insulin and glucagon response to glucose concentrations of $25,50,150$, and $350 \mathrm{mg} / 100 \mathrm{ml}$ was investigated. The effect of gastrin, pancreozymin, and secretin as well as that of the amino acid arginine was investigated at low $(25$ or $50 \mathrm{mg} / 100 \mathrm{ml}$ ) concentrations of glucose and at a

${ }^{1}$ 1970. Klin. Wochenschr. 48: 65. glucose concentration of $150 \mathrm{mg} / 100 \mathrm{ml}$ in the perfusate. To ensure that the response seen after one stimulus was not affected by the prior treatment of the pancreas, the order of stimulation and changes of glucose were reversed. At the end of each experiment, the insulin response to a glucose concentration of $350 \mathrm{mg} / 100 \mathrm{ml}$ was checked in order to prove that the beta cells were still capable of the characteristic biphasic insulin response.

\section{RESULTS}

Effect of different concentrations of glucose in the perfusate upon secretion of glucagon and insulin. In six perfusion experiments with glucose concentrations of 25 $\mathrm{mg} / 100 \mathrm{ml}$ or $50 \mathrm{mg} / 100 \mathrm{ml}$ in the perfusing medium, a mean glucagon concentration in the efflux of 0.46 $\mathrm{ng} / \mathrm{ml}$ (SEM \pm 0.09 ) was obtained (Figs. $2-4$ and Table I). The insulin concentration at this concentration of glucose was $10-25 \mu \mathrm{U} / \mathrm{ml}$. The sudden increase in the glucose concentration in the perfusing medium to 150 $\mathrm{mg} / 100 \mathrm{ml}$ immediately suppressed the glucagon output to a mean value of $0.16 \mathrm{ng} / \mathrm{ml}$ ( $\mathrm{SEM} \pm 0.04)$. Glucose concentrations of $150 \mathrm{mg} / 100 \mathrm{ml}$ elicited the well-known pattern of insulin release, a prompt rise in insulin during 

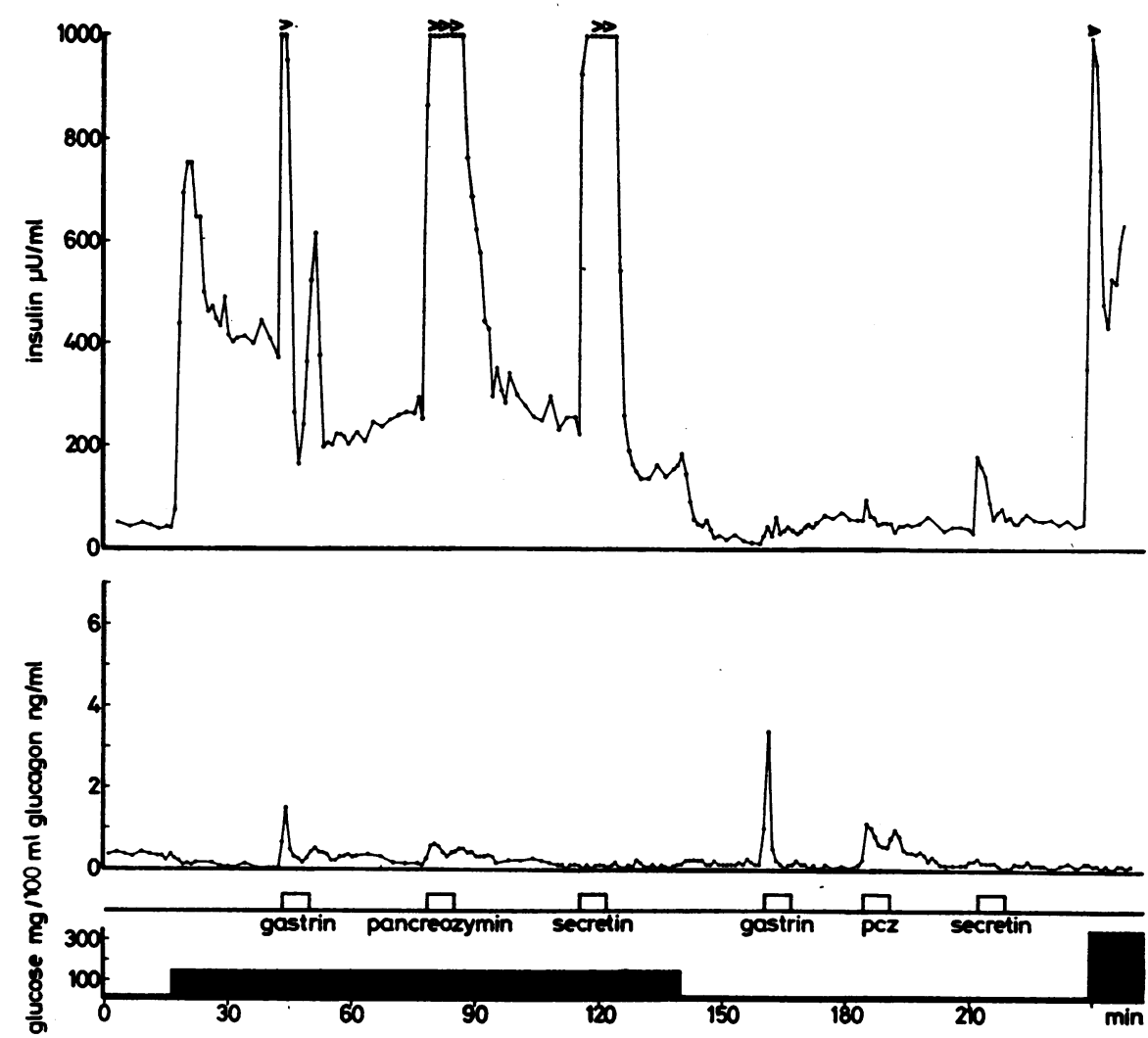

FIGURE 4 Effect of pancreozymin, secretin, and gastrin upon the secretion of pancreatic glucagon and insulin during perfusion with a glucose concentration of 25 $\mathrm{mg} / 100 \mathrm{ml}$ and $150 \mathrm{mg} / 100 \mathrm{ml}$. $\rightarrow, 1672 \mu \mathrm{U} / \mathrm{ml}$ peak value; $>, 1200,2248 \mu \mathrm{U} / \mathrm{ml}$; $>>, 5154,3992,2824,1888,2792,2968,3032,2528,3000 \mu \mathrm{U} / \mathrm{ml} ;>>, 2248,1584$, $1248,1032,1160,1040,1104,1336 \mu \mathrm{U} / \mathrm{ml}$.

TABLE I

Effect of Glucose on the Secretion of Pancreatic Glucagon (PG:ng/ml) in Six Perfusion Experiments

\begin{tabular}{cccccccc}
\hline Experiment & \multicolumn{7}{c}{ Glucose concentration in perfusate } \\
\hline & \multicolumn{2}{c}{$25 \mathrm{mg} / 100 \mathrm{ml}$} & $150 \mathrm{mg} / 100 \mathrm{ml}$ & $25 \mathrm{mg} / 100 \mathrm{ml}$ & $\begin{array}{c}(25 \rightarrow 150) \\
\mathrm{mg} / 100 \mathrm{ml}\end{array}$ & $\begin{array}{c}(150 \rightarrow 25) \\
\mathrm{mg} / 100 \mathrm{ml}\end{array}$ \\
28 & $0.47 \pm 0.05^{*}$ & $(6) \ddagger$ & $0.08 \pm 0.01(12)$ & $0.35 \pm 0.11(8)$ & $P<0.001 \|$ & $P<0.025$ \\
5 & $0.48 \pm 0.05$ & $(7)$ & $0.26 \pm 0.01(12)$ & $0.53 \pm 0.02(18)$ & $P<0.001$ & $P<0.001$ \\
8 & $0.36 \pm 0.02$ & $(10)$ & $0.16 \pm 0.03(15)$ & $0.48 \pm 0.05(12)$ & $P<0.001$ & $P<0.001$ \\
24 & $0.87 \pm 0.10$ & $(5)$ & $0.29 \pm 0.01(11)$ & $0.61 \pm 0.04$ & $(8)$ & $P<0.001$ & $P<0.001$ \\
13 & $0.23 \pm 0.04$ & $(8)$ & $0.09 \pm 0.01(16)$ & $0.18 \pm 0.02$ & $(8)$ & $P<0.02$ & $P<0.01$ \\
26 & $0.33 \pm 0.01$ & $(10)$ & $0.09 \pm 0.01(19)$ & $0.18 \pm 0.01$ & $(8)$ & $P<0.001$ & $P<0.001$ \\
Mean \pm SEM & $0.46 \pm 0.09$ & $(6) \S$ & $0.16 \pm 0.04(6)$ & $0.39 \pm 0.07$ & $(6)$ & $P<0.025$ & $P<0.05$ \\
\hline
\end{tabular}

\footnotetext{
* Mean ISEM.
}

$\ddagger$ Number of samples obtained in each period. The first sample after changing the glucose concentration from $(25 \rightarrow 150) \mathrm{mg} / 100 \mathrm{ml}$ is not included.

$\S$ Number of experiments.

$\| P$, values using Student's $t$ test. 
approximately 2-3 min which was followed by a rapid decline leveling off to values of about half the peak value. By changing the glucose concentration in the perfusate back to $25 \mathrm{mg} / 100 \mathrm{ml}$ or $50 \mathrm{mg} / 100 \mathrm{ml}$ the mean glucagon concentration again rose within 1 or $2 \mathrm{~min}$ to levels characteristic of low glucose concentrations 0.39 $\mathrm{ng} / \mathrm{ml}$ (SEM \pm 0.07 ) and insulin returned to low values. These changes in the secretion of glucagon and insulin could be repeatedly shown after alterations in perfusate glucose throughout the experiment in most of the experiments. In experiments where the pancreas was perfused with a low glucose concentration for 2-3 hr before the glucagon concentration was increased to 150 $\mathrm{mg} / 100 \mathrm{ml}$ and where it had been intensively stimulated with gastrin and pancreozymin, the inhibition of glucagon secretion following change in glucose appeared less obvious and was in some instances absent. At the end of each experiment, the glucose concentration was increased to $350 \mathrm{mg} / 100 \mathrm{ml}$. At this glucose concentration glucagon secretion was not further inhibited (see Discussion). This high glucose concentration always elicited the normal biphasic insulin response to an increment in glucose.
Effects of gastrin, pancreozymin, and secretin during perfusion with glucose concentrations of 25, 50, and $150 \mathrm{mg} / 100 \mathrm{ml}$. Stimulation of glucagon secretion was obtained in each of 4 perfusion experiments with an infusion of gastrin (65 ng/ml for $8 \mathrm{~min}$ ) and in each of 10 perfusion experiments with an infusion of pancreozymin $(1.5 \mathrm{U} / \mathrm{ml}$ for $6-8 \mathrm{~min})$, while stimulation was not observed after an infusion of secretin (0.35 $\mathrm{U} / \mathrm{ml}$ for 5-8 $\mathrm{min}$ ) in any of 6 perfusion experiments. Representative experiments of these different stimulations are shown in Figs. 2-5.

The stimulatory effect of gastrin and pancreozymin on glucagon secretion was most pronounced during perfusion with the lower glucose concentration in the perfusate. The mean glucagon level after a gastrin infusion rose from $0.19 \mathrm{ng} / \mathrm{ml}(\mathrm{SEM} \pm 0.06)$ to a peak of 3.72 $\mathrm{ng} / \mathrm{ml}(\operatorname{SEM} \pm 0.02)$ at $2 \mathrm{~min}$; after a pancreozymin infusion it rose from $0.36 \mathrm{ng} / \mathrm{ml}$ (SEM \pm 0.07 ) to a peak of $4.59 \mathrm{ng} / \mathrm{ml}$ ( $\mathrm{sEM} \pm 1.11$ ). However, increases in glucagon secretion were also observed at a glucagon concentration of $150 \mathrm{ng} / 100 \mathrm{ml}$, which by itself effectively inhibits glucagon secretion. Thus the mean glucagon level after gastrin rose from $0.15 \mathrm{ng} / \mathrm{ml}$ (SEM
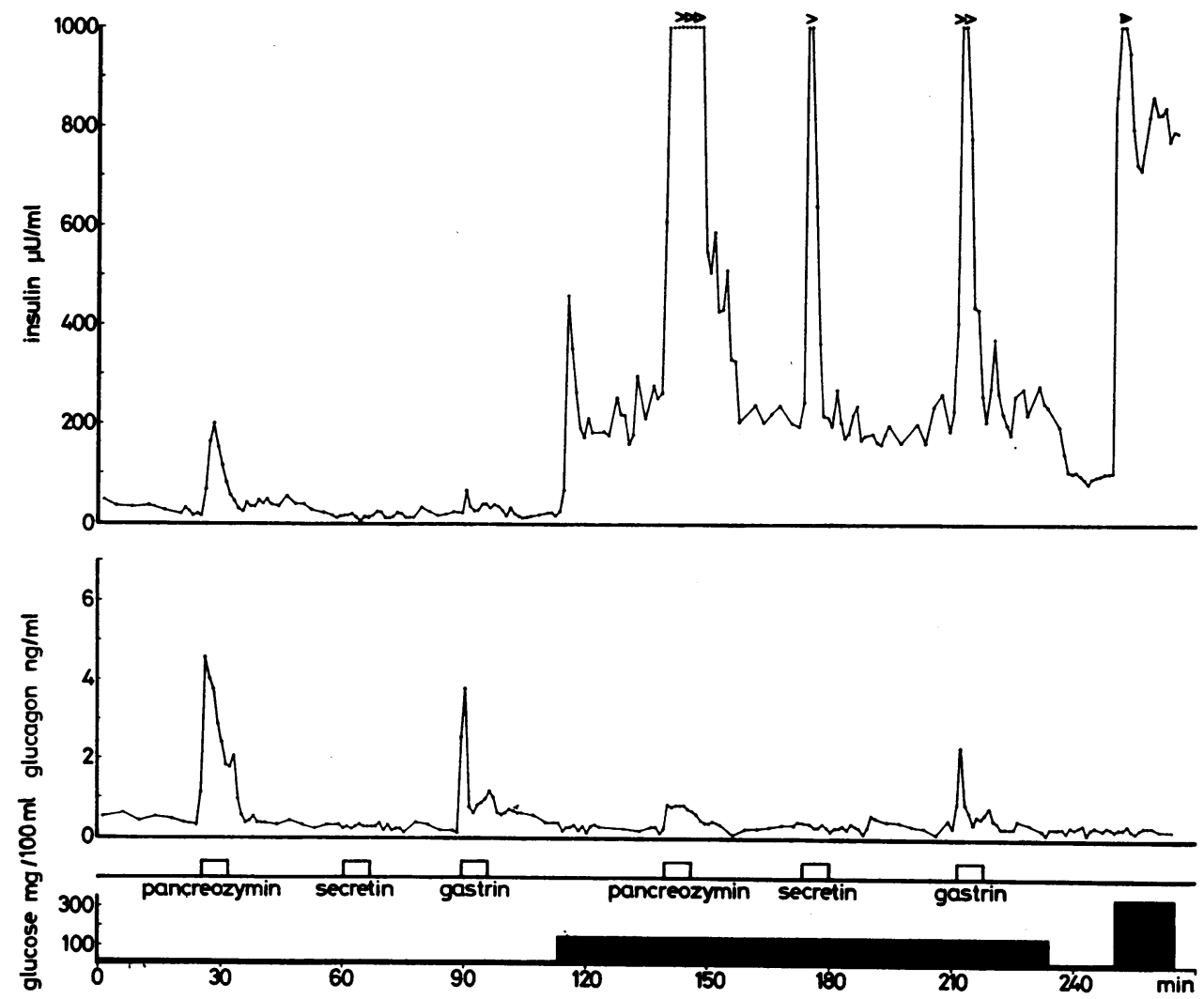

FIGURE 5 Effect of pancreozymin, secretin, and gastrin upon the secretion of pancreatic glucagon and insulin during perfusion with a glucose concentration of $25 \mathrm{mg} / 100 \mathrm{ml}$ and 150 $\mathrm{mg} / 100 \mathrm{ml} . \longrightarrow$, peak value $1672 \mu \mathrm{U} / \mathrm{ml} ;>>, 2922,2240,1152,1216,1000,1216,1608,1160$ $\mu \mathrm{U} / \mathrm{ml} ;>, 1496,1692 \mu \mathrm{U} / \mathrm{ml} ;>>, 2041,1556 \mu \mathrm{U} / \mathrm{ml}$. 


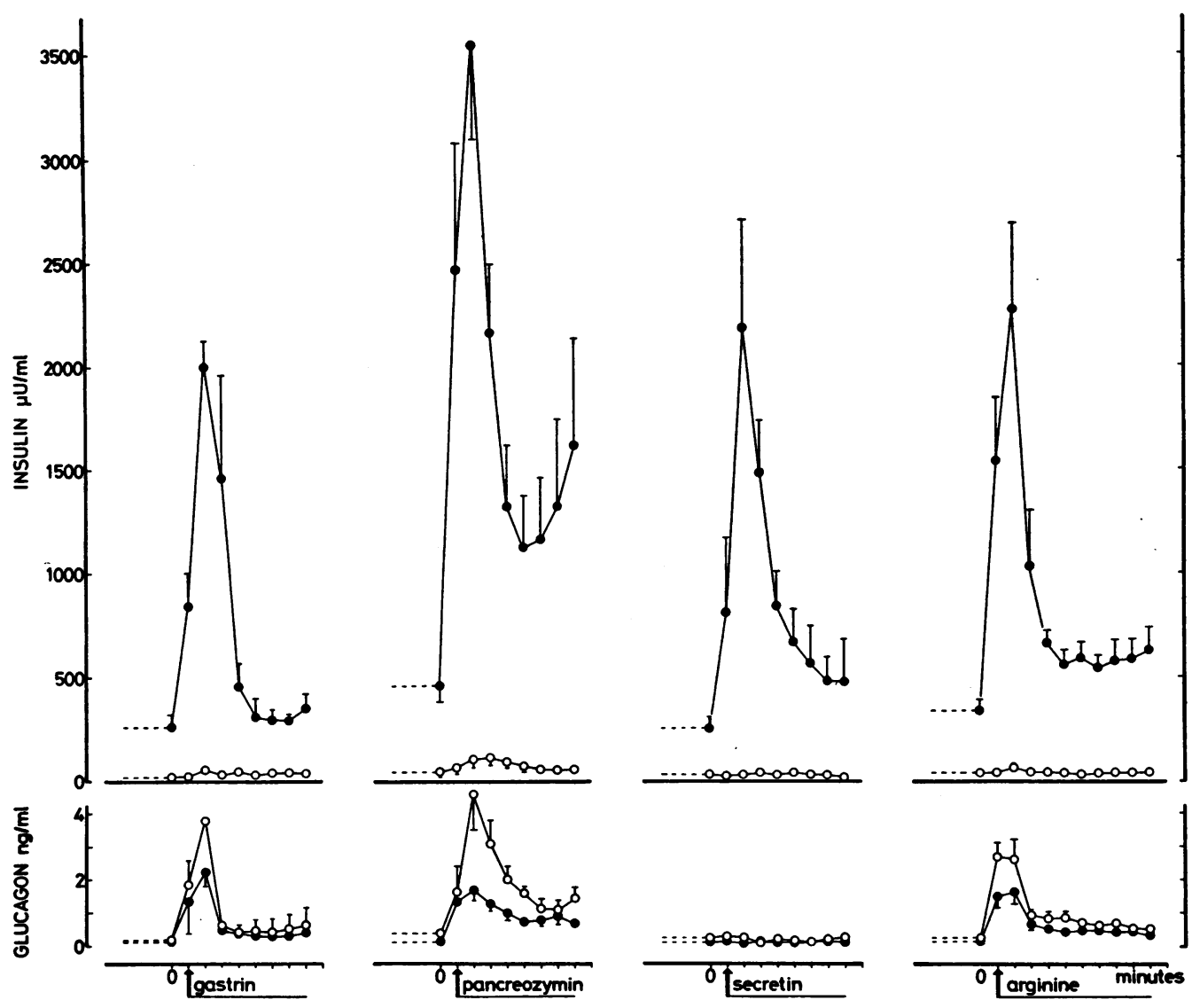

FIgURE 6 Mean values of glucagon and insulin \pm SEM in the various stimulation periods from the different perfusion experiments. Stimulation with gastrin during perfusion with a glucose concentration of $150 \mathrm{mg} / 100 \mathrm{ml}(\bullet-\bullet)(\mathrm{n}=4)$, during perfusion with a glucose concentration of $25 \mathrm{mg} / 100 \mathrm{ml}(\mathrm{O})(\mathrm{n}=2)$, pancreozymin $(\bullet-\bullet)(\mathrm{n}=10)$, $(\mathrm{O}-\mathrm{O})(\mathrm{n}=7)$, secretin $(\bullet-\bullet)(\mathrm{n}=6),(\mathrm{O}-\mathrm{O})(\mathrm{n}=2)$, and arginine $(\bullet-\bullet)$ $(n=8),(O-O)(n=7)$. The values at the zero points indicate the hormone concentration (Mean \pm SEM) in the prestimulation period.

$\pm 0.10)$ to a peak of $2.21 \mathrm{ng} / \mathrm{ml}(\operatorname{SEM} \pm 0.43)$ at $2 \mathrm{~min}$; after pancreozymin it rose from $0.14 \mathrm{ng} / \mathrm{ml}$ (SEM $\pm 0.02)$ to a peak of $1.67 \mathrm{ng} / \mathrm{ml}(\mathrm{SEM} \pm 0.30)$. Infusion of secretin was associated with no rise in glucagon secretion either during perfusion with a glucose concentration of $25 \mathrm{mg} / 100 \mathrm{ml}$ or of $150 \mathrm{mg} / 100 \mathrm{ml}$. The glucagon response to gastrin and to pancreozymin was biphasic, i.e. within $1 \mathrm{~min}$ after start of the infusion a sharp, prompt rise to $3-6 \mathrm{ng} / \mathrm{ml}$ occurred, which subsided within $1 \mathrm{~min}$ and was followed by a rapid decline until the concentration leveled off at a value of about $0.6-0.7 \mathrm{ng} / \mathrm{ml}$. The enhanced secretion stopped immediately after termination of both the gastrin and the pancreozymin infusion. The secretion of glucagon thus exhibits a biphasic release pattern similar to that described for insulin.

In contradistinction an instantaneous very large increase in insulin secretion always occurred after an infusion of gastrin, pancreozymin, or secretin during perfusion with a glucose concentration of $150 \mathrm{mg} / 100$ $\mathrm{ml}$. The mean insulin level after gastrin infusion rose from $264.0 \mu \mathrm{U} / \mathrm{ml}(\mathrm{SEM} \pm 61.2)$ to a peak of $2000 \mu \mathrm{U} / \mathrm{ml}$ ( $\operatorname{sEM} \pm 126.3)$; after pancreozymin it rose from 428.5 $\mu \mathrm{U} / \mathrm{ml}$ (SEM \pm 81.3 ) to a peak of $3551 \mu \mathrm{U} / \mathrm{ml}$ (SEM \pm 452.5 ) and after secretin it rose from $253.0 \mu \mathrm{U} / \mathrm{ml}$ (SEM $\pm 59.6)$ to a peak of $2187 \mu \mathrm{U} / \mathrm{ml}(\mathrm{SEM} \pm 520.4)$. All the peaks occurred at $2 \mathrm{~min}$. The increased insulin output after these stimuli showed the characteristic biphasic response pattern, previously described after an increment in glucose $(20,21)$. The stimulatory effect of the intestinal hormones was not consistently present during perfusion with a glucose concentration of $25 \mathrm{mg} /$ $100 \mathrm{ml}$. However, in three experiments, which were carried out at a glucose concentration of $50 \mathrm{mg} / 100 \mathrm{ml}$ an effect was always observed. The difference in insulin response after pancreozymin at different glucose 
TABLE II

Effect of Gastrin on the

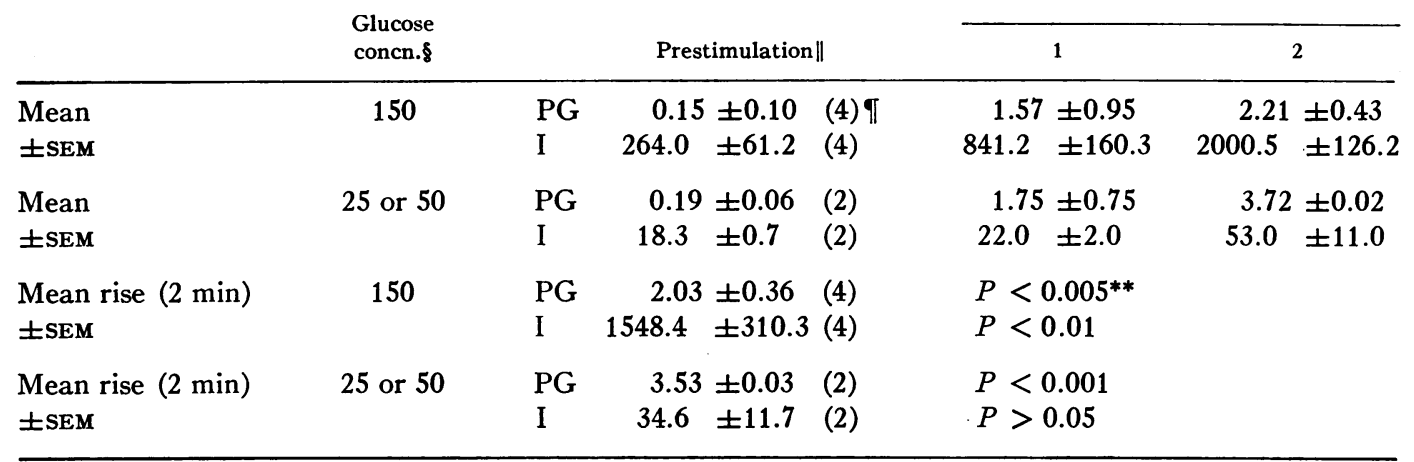

* Pancreatic glucagon $\mathrm{ng} / \mathrm{ml}$.

$\ddagger$ Insulin $\mu \mathrm{U} / \mathrm{ml}$.

\$ Glucose concentration in the perfusate $\mathrm{mg} / 100 \mathrm{ml}$.

$\|$ The prestimulation period is defined as the 10-15 min preceding infusion of the stimulatory substance. The prestimulation value in each experiment is the mean of about 10 samples.

T Number of experiments.

${ }^{* *} P$, values using Student's $t$ test.

concentrations can be seen in Figs. 2 and 3. The mean results are recorded in Tables II-IV. In Fig. 6 the mean results of the stimulation periods from the different perfusion experiments are depicted.

A representative experiment of reversing the order of stimulation and change of glucose is given in Figs. 4 and 5. As will be seen the same glucose dependence was obtained.

Effect of arginine during perfusion with a glucose concentration of 25,50 , and $150 \mathrm{mg} / 100 \mathrm{ml}$. The effect of infusion of arginine $(4.3 \mathrm{~mm}$ for $10 \mathrm{~min}$ ) on glucagon output was studied in nine perfusion experiments, at low glucose concentrations as well as at the high concentration of glucose which effectively inhibits glucagon secretion in our experiments. The mean glucagon level rose during perfusion with a glucose concentration of $25 \mathrm{mg} / 100 \mathrm{ml}$ from $0.25 \mathrm{ng} / \mathrm{ml}$ (SEM $\pm 0.01)$ to a peak of $2.60 \mathrm{ng} / \mathrm{ml}(\operatorname{seM} \pm 0.61)$ at $2 \mathrm{~min}$; during perfusion with a glucose concentration of 150 $\mathrm{mg} / 100 \mathrm{ml}$ it rose from $0.15 \mathrm{ng} / \mathrm{ml}$ ( $\mathrm{SEM} \pm 0.03$ ) to a peak of $1.63 \mathrm{ng} / \mathrm{ml}(\mathrm{SEM} \pm 0.34)$ at $2 \mathrm{~min}$. The pattern of response was biphasic, identical to that seen after

TABLE III

Effect of Pancreozymin on the

\begin{tabular}{|c|c|c|c|c|c|}
\hline & \multirow{2}{*}{$\begin{array}{l}\text { Glucose- } \\
\text { concn.\& }\end{array}$} & \multirow{2}{*}{\multicolumn{2}{|c|}{ Prestimulation\| }} & \\
\hline & & & & 1 & 2 \\
\hline \multirow{2}{*}{$\begin{array}{l}\text { Mean } \\
\pm \text { SEM }\end{array}$} & \multirow[t]{2}{*}{150} & PG & \multirow{2}{*}{$\begin{aligned} 0.14 & \pm 0.02(10) ף \\
428.5 & \pm 81.3 \quad(10)\end{aligned}$} & $1.33 \pm 0.07$ & $1.67 \pm 0.30$ \\
\hline & & I & & $2469.0 \pm 613.3$ & $3550.8 \pm 452.5$ \\
\hline \multirow{2}{*}{$\begin{array}{l}\text { Mean } \\
\pm \text { SEM }\end{array}$} & \multirow{2}{*}{25 or 50} & PG & $0.36 \pm 0.07$ & $1.80 \pm 0.77$ & $4.59 \pm 1.11$ \\
\hline & & I & $40.3 \pm 6.39$ & $57.8 \pm 20.7$ & $103.1 \pm 31.0$ \\
\hline \multirow{2}{*}{$\begin{array}{l}\text { Mean rise }(2 \mathrm{~min}) \\
\pm \mathrm{SEM}\end{array}$} & \multirow[t]{2}{*}{150} & PG & $1.59 \pm 0.33$ & $P<0.001^{* *}$ & \\
\hline & & & $3154.4 \pm 456.6(10)$ & $P<0.001$ & \\
\hline \multirow{2}{*}{$\begin{array}{l}\text { Mean rise }(2 \mathrm{~min}) \\
\pm \mathrm{SEM}\end{array}$} & \multirow[t]{2}{*}{25 or 50} & PG & $4.23 \pm 1.05$ & $P<0.01$ & \\
\hline & & I & $62.9 \pm 26.8$ & $P<0.05$ & \\
\hline
\end{tabular}

See footnotes Table II. 
Secretion of $P G^{*}$ and $I \ddagger$

\begin{tabular}{cccccc}
\hline \multicolumn{7}{c}{ Concentrations during stimulation } \\
\hline \multicolumn{7}{c}{ Time, $\min$} \\
\hline 3 & 4 & 5 & 6 & 7 & 8 \\
\hline $0.48 \pm 0.13$ & $0.38 \pm 0.10$ & $0.30 \pm 0.05$ & $0.30 \pm 0.08$ & $0.30 \pm 0.06$ & $0.41 \pm 0.09$ \\
$1459.5 \pm 493.9$ & $456.0 \pm 117.9$ & $303.7 \pm 85.8$ & $292.5 \pm 55.7$ & $290.7 \pm 25.0$ & $350.5 \pm 66.9$ \\
$0.62 \pm 0.11$ & $0.40 \pm 0.20$ & $0.45 \pm 0.35$ & $0.42 \pm 0.42$ & $0.52 \pm 0.42$ & $0.62 \pm 0.52$ \\
$27.5 \pm 4.5$ & $42.0 \pm 18.0$ & $27.0 \pm 2.0$ & $36.0 \pm 2.0$ & $38.5 \pm 2.5$ & $31.5 \pm 1.5$
\end{tabular}

stimulation with gastrin and pancreozymin and again the response was most pronounced during perfusion with a low glucose concentration of $25 \mathrm{mg} / 100 \mathrm{ml}$ or $50 \mathrm{mg} / 100 \mathrm{ml}$ (Figs. 2 and 3 ).

No rise in insulin secretion occurred after an infusion of arginine during perfusion with a glucose concentration of $25 \mathrm{mg} / 100 \mathrm{ml}$ (Fig. 2) while a consistent, although small increase in insulin was seen during perfusion with the slightly higher glucose concentration of $50 \mathrm{mg} / 100 \mathrm{ml}$ (Fig. 3). At $150 \mathrm{mg} / 100 \mathrm{ml}$ of glucose in the perfusate a biphasic, instantaneous and large in- crease in insulin secretion was observed (Figs. 2 and 3). The mean insulin level rose from $314.7 \mu \mathrm{U} / \mathrm{ml}$ (SEM \pm 50.9 ) to a peak at $2 \mathrm{~min}$ of $2271 \mu \mathrm{U} / \mathrm{ml}$ (SEM \pm 420 ). After termination of the infusion there was a rather pronounced fall of insulin followed by a second rise back to prestimulation levels. The mean results are condensed in Table V. In Fig. 6 the mean results of the stimulation periods from the different perfusion experiments are depicted.

The time interrelationship between the glucagon and the insulin response after stimulation with gastrin, pan-

Secretion of $P G^{*}$ and $I \ddagger$

\begin{tabular}{|c|c|c|c|c|c|}
\hline \multicolumn{6}{|c|}{ Concentrations during stimulation } \\
\hline \multicolumn{6}{|c|}{ Time, $\min$} \\
\hline 3 & 4 & 5 & 6 & 7 & 8 \\
\hline $1.26 \pm 0.21$ & $0.98 \pm 0.17$ & $0.72 \pm 0.13$ & $0.78 \pm 0.16$ & $0.90 \pm 0.22$ & $0.68 \pm 0.13$ \\
\hline $2165.8 \pm 333.1$ & $1325.5 \pm 297.9$ & $1127.8 \pm 254.3$ & $1162.6 \pm 290.7$ & $1325.4 \pm 427.8$ & $1621.7 \pm 516.7$ \\
\hline $3.08 \pm 0.72$ & $2.00 \pm 0.54$ & $1.59 \pm 0.41$ & $1.10 \pm 0.25$ & $1.08 \pm 0.32$ & $1.43 \pm 0.34$ \\
\hline $110.2 \pm 27.7$ & $89.1 \pm 21.5$ & $68.4 \pm 17.0$ & $53.1 \pm 11.2$ & $51.7 \pm 10.1$ & $53.3 \pm 1.66$ \\
\hline
\end{tabular}


TABLE IV

Effect of Secretin on the

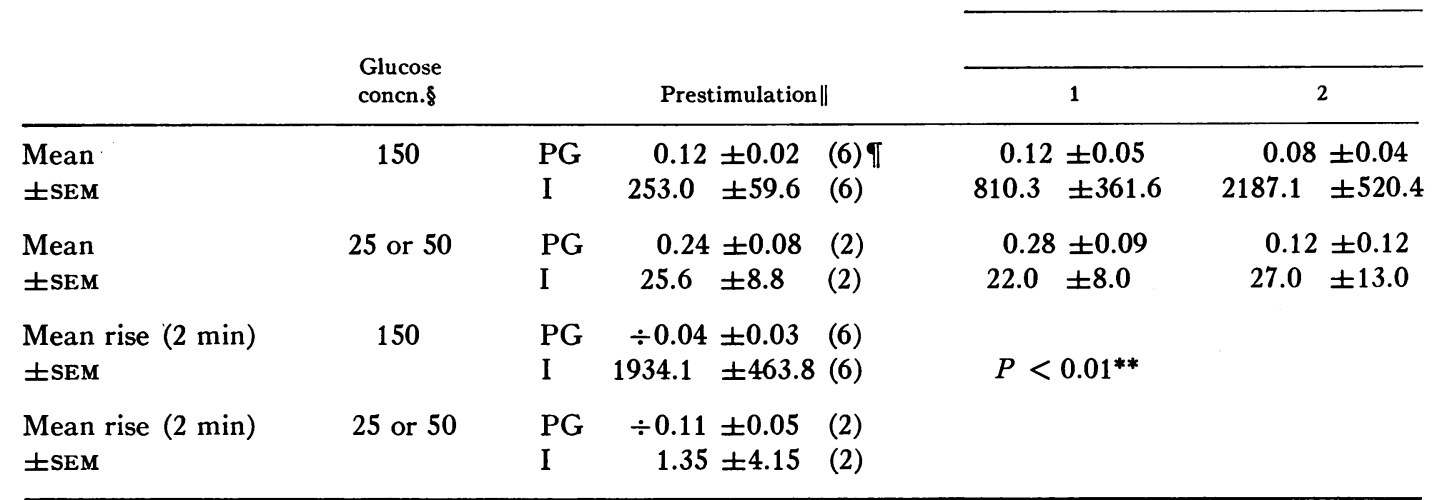

See footnotes Table II.

creozymin, and arginine. The response of glucagon and insulin to gastrin, pancreozymin and to arginine infusion occurred simultaneously during perfusion with a glucose concentration of 25,50 , and $150 \mathrm{mg} / 100 \mathrm{ml}$. In these studies, effluent samples were collected at $5 \mathrm{sec}$ intervals during the first 2 min after addition of stimulus. The first detectable rise in glucagon and insulin occurred in the same $5 \mathrm{sec}$ sample in five experiments, or in consecutive samples where the insulin rise preceded the glucagon rise in five experiments, and glucagon preceded insulin in seven experiments. In the experiments where the rise in glucagon and insulin did not occur in the same $5 \mathrm{sec}$ sample the first detectable rise occurred for that hormone which showed the greatest relative rise after stimulations. Insulin thus preferentially preceded glucagon at high glucose concentrations, while the opposite time pattern of secretion was found at low glucose concentrations. The delay before the initial rise coincides in the present in vitro preparation with the time it takes for the stimulus to reach the islets of Langerhans. Fig. 7 shows representative situations of the time interrelationship of the secretion of glucagon and insulin in three different perfusion experiments during perfusion with a glucose concentration of 150 $\mathrm{mg} / 100 \mathrm{ml}$.

\section{DISCUSSION}

In the present investigation results are reported on the secretion of pancreatic glucagon from the isolated, perfused canine pancreas.

In vitro studies on the secretion of pancreatic glucagon have been very few. Results from isolated islet systems $(22,23)$ have shown that high glucose concentrations inhibit glucagon release. Pancreozymin was found

TABLE V

Effect of Arginine on the

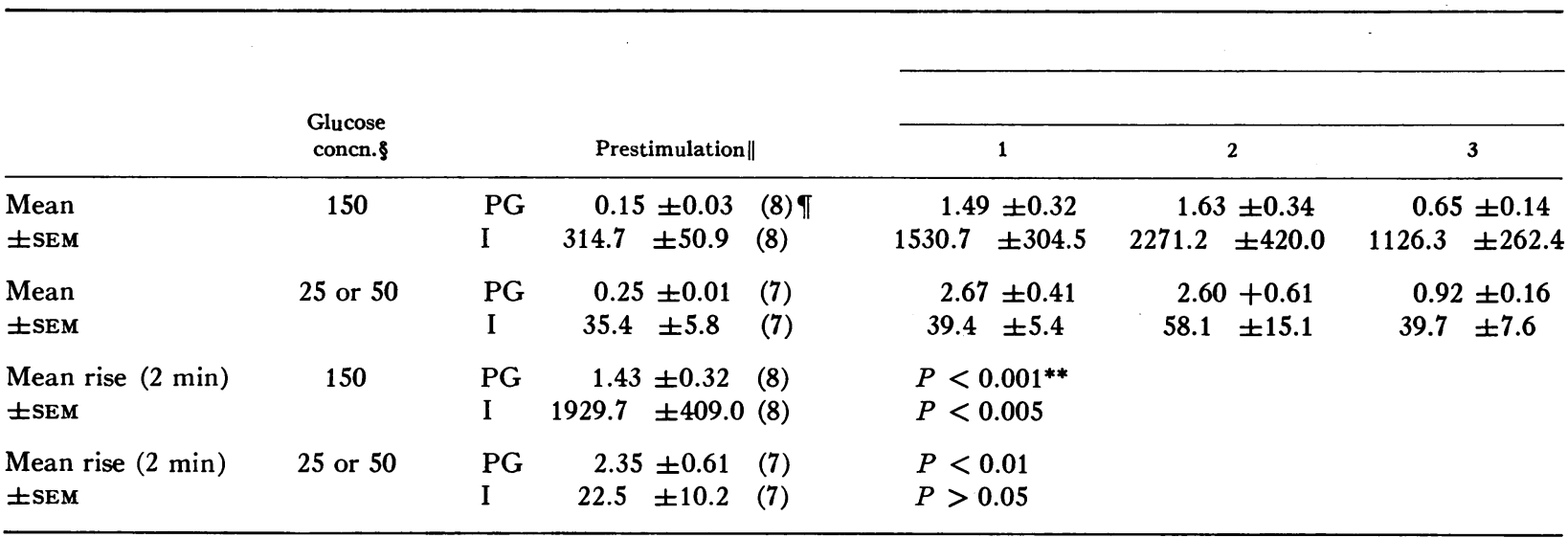

See footnotes Table II. 


\begin{tabular}{cccccc}
\hline \multicolumn{7}{c}{ Concentrations during stimulation } \\
\hline \multicolumn{7}{c}{ Time, $\min$} \\
\hline 3 & 4 & 5 & 6 & 7 & 8 \\
\hline $0.14 \pm 0.05$ & $0.12 \pm 0.04$ & $0.11 \pm 0.04$ & $0.13 \pm 0.05$ & $0.14 \pm 0.05$ & $0.11 \pm 0.05$ \\
$1454.0 \pm 255.3$ & $842.8 \pm 170.7$ & $666.8 \pm 151.9$ & $567.8 \pm 181.0$ & $480.6 \pm 159.5$ & $474.2 \pm 211.3$ \\
$0.10 \pm 0.10$ & $0.20 \pm 0.05$ & $0.16 \pm 0.13$ & $0.12 \pm 0.11$ & $0.20 \pm 0.00$ & - \\
$37.0 \pm 20.0$ & $25.0 \pm 15.0$ & - & $26.5 \pm 14.5$ & $25.0 \pm 15.0$ & -
\end{tabular}

to be unable to stimulate glucagon secretion, and pancreozymin, secretin, and gastrin did not release insulin. This is in variance with findings in vivo as well as with the findings in the present in vitro study. One rather obvious explanation would be that the environment of the islets is altered radically and that the islets have become insensitive to hormone releasing stimuli during the isolation procedure.

The isolated, perfused canine pancreas preparation described in this paper has proven to be a useful tool and a reliable model for studying secretion of both pancreatic glucagon and insulin.

The results reported in this paper demonstrate, under the experimental conditions obtaining in this study, that high glucose concentrations suppress the secretion of pancreatic glucagon while low glucose concentrations enhance the secretion. The results thus support the con- cept of a role of glucagon as a "hormone of glucose need" as developed from various types of in vivo studies. The results show that acute changes in the glucose concentration of the perfusion medium exert an immediate effect on the secretion of pancreatic glucagon. It may be inferred that pancreatic glucagon may function in a moment to moment control of glucose concentration in blood, as has been suggested in the studies of Ohneda and coworkers (9).

No consistent inhibition of glucagon secretion was observed at the late high glucose concentration in most experiments, which might have been expected. However, glucagon release had been intensively stimulated with intestinal hormones or arginine, thus making suppression of glucagon less likely. It should be stressed in this connection, that the response pattern of glucagon and insulin after stimulation with the intestinal hor-

Secretion of $P G^{*}$ and I

\begin{tabular}{|c|c|c|c|c|c|c|}
\hline \multicolumn{7}{|c|}{ Concentrations during stimulation } \\
\hline \multicolumn{7}{|c|}{ Time, $\min$} \\
\hline 4 & 5 & 6 & 7 & 8 & 9 & 10 \\
\hline $0.53 \pm 0.07$ & $0.42 \pm 0.07$ & $0.46 \pm 0.07$ & $0.46 \pm 0.10$ & $0.43 \pm 0.09$ & $0.45 \pm 0.13$ & $0.32 \pm 0.09$ \\
\hline $651.6 \pm 56.0$ & $559.2 \pm 69.6$ & $588.6 \pm 75.1$ & $550.7 \pm 60.4$ & $576.5 \pm 98.7$ & $584.5 \pm 95.1$ & $628.4 \pm 109.4$ \\
\hline $0.83 \pm 0.20$ & $0.85 \pm 0.20$ & $0.69 \pm 0.10$ & $0.63 \pm 0.13$ & $0.68 \pm 0.06$ & $0.55 \pm 0.09$ & $0.51 \pm 0.09$ \\
\hline $39.5 \pm 7.3$ & $37.4 \pm 6.3$ & $30.4 \pm 5.4$ & $32.3 \pm 5.4$ & $34.4 \pm 6.8$ & $36.3 \pm 4.4$ & $38.1 \pm 9.4$ \\
\hline
\end{tabular}



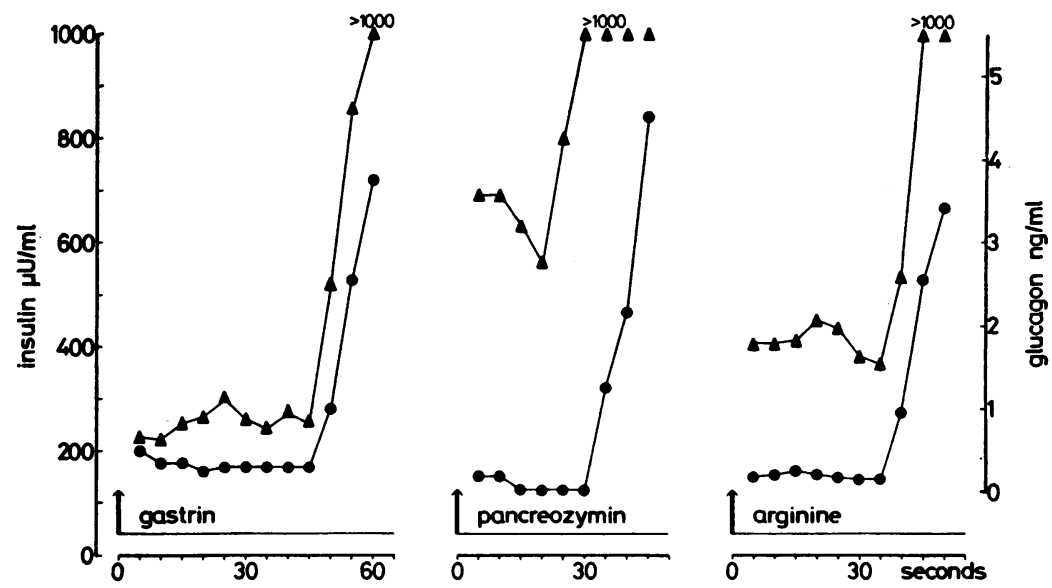

FIGURE 7 The time interrelationship of the initial rise of the secretion of pancreatic glucagon and insulin during perfusion with a glucose concentration of $150 \mathrm{mg} / 100 \mathrm{ml}$ following gastrin, pancreozymin, and arginine $(\boldsymbol{\Delta}-\mathbf{\Delta}$ insulin, $\longrightarrow$ glucagon).

mones and arginine, and the dependence of the response pattern upon the glucose concentration present in the perfusing medium remained the same during the experiments, proving intact responsiveness of the alpha cells within the experimental period.

Gastrin, pancreozymin, as well as arginine were able to stimulate secretion of pancreatic glucagon, whereas secretin was without effect. Our results are thus consistent with in vivo data from experiments on triply catheterized dogs $(5,7,8)$ with respect to the effects of pancreozymin, secretin, and arginine. Our finding, however, that gastrin, given as the synthetic human type I, stimulates glucagon release, has thus far not been reported. Recent data (19), that the synthetic C-terminal tetrapeptide amide of gastrin caused an elevation in the pancreaticoduodenal vein glucagon in dogs is interesting in this connection. However, it would be difficult to conclude from this finding that gastrin itself was effective in stimulating secretion of glucagon, as the C-terminal tetrapeptide amide is shared by both the gastrin and the pancreozymin molecule. The reason that Dupré, Curtis, Unger, Waddell, and Beck were unable to show a glucagon releasing effect of gastrin may be that a crude extract of hog antrum was used (2).

In addition, the present results demonstrate that the secretion of pancreatic glucagon after stimulation with gastrin, pancreozymin, and arginine follows a biphasic release pattern not previously described, similar to the characteristic response pattern described for insulin. The biphasic response pattern appears to be a characteristic feature of the secretion of the pancreatic hormones. A two pool model for insulin secretion has been proposed to explain this phenomenon $(24,25)$. In an earlier publication from our laboratory evidence for a feedback inhibition of insulin on insulin secretion has been reported in the isolated, perfused canine pancreas (13). The biphasic insulin response could be explained as a result of glucose or other stimulation plus feedback inhibition as has been originally discussed by Grodsky, Bennett, Smith, and Nemechek (20) and Bennett and Grodsky (21). The same hypothesis might also be relevant for the understanding of the biphasic glucagon response pattern, however, further experiments with special reference to this particular problem are necessary.

Although the high glucose concentration of $150 \mathrm{mg} /$ $100 \mathrm{ml}$ in the perfusing fluid was unable to abolish the stimulatory effect of gastrin, pancreozymin, and arginine on the secretion of pancreatic glucagon, it did reduce the response in comparison with stimulation during perfusion with a low glucose concentration. From the point of view of the organism as a whole it is difficult to understand why glucagon secretion should be increased by gastrin, pancreozymin, or arginine at a glucose concentration of $150 \mathrm{mg} / 100 \mathrm{ml}$. Several explanations present themselves. Enhanced secretion in a situation where there is a demand for insulin might be explained by the ability of pancreatic glucagon to stimulate release of insulin (see later). On the other hand it would seem provident from the point of view of glucose homeostasis in a later phase if a glycogenolytic hormone-like glucagon was secreted simultaneously with insulin to prevent a possible postabsorptive hypoglycemia due to overwhelming aminogenic insulin secretion. Still a third possibility might exist, i.e. that glucagon apart from being an important hormone in carbohydrate metabolism is a hormone necessary for the 
handling of amino acids $(26,27)$. This explanation is supported by the fact that a rise in glucagon is seen after stimuli associated with protein intake $(28,29)$. Finally, the concentrations of the intestinal hormones used in this study were rather high and maybe above a physiological range.

Pancreatic glucagon has been reported to be a potent stimulus of insulin secretion in in vivo $(30,31)$ as well as in in vitro experiments (32-34). The precise nature of the stimulatory effect in vivo upon insulin secretion by pancreatic glucagon is not known. However, because of the rapid destruction of pancreatic glucagon and the negligible amount of pancreatic glucagon in peripheral blood, it may be assumed that if pancreatic glucagon is insulinogenic in vivo the stimulatory effect of pancreatic glucagon must take place locally immediately after secretion of the glucagon from the alpha cells of the islets of Langerhans and before recirculation. More direct evidence for such local eliciting effect of pancreatic glucagon might be offered, if the secretion of pancreatic glucagon, after stimuli such as gastrin, pancreozymin, and arginine, preceded secretion of insulin. Our results demonstrate that the secretion of the two hormones occurred simultaneously.

The present findings are consistent with the observations of Unger et al. made in dogs, but at variance with the results obtained in the isolated, perfused rat pancreas by Fussgänger et al. (35), who found that the secretion of glucagon after pancreozymin was delayed 5-10 min after the initial rise in insulin. However, the spontaneously increasing glucagon level during perfusion with a high glucose concentration, reported in this paper, may call for caution in the interpretation of the results.

The results of the time relationship experiments did not indicate an insulinogenic action of endogenous pancreatic glucagon. The finding in this study that secretin is able to stimulate secretion of insulin without any enhancement of pancreatic glucagon secretion speaks against a role of pancreatic glucagon as a necessary condition for insulin secretion after any kind of stimulus. Furthermore, the finding reported here that changes in insulin and glucagon secretion are consistently in opposite directions at high as compared with low glucose concentrations in the perfusing medium, also following stimulation with gastrin, pancreozymin, and arginine, speaks against such a role.

\section{ACKNOWLEDGMENTS}

I am very grateful to Professor Tyge S $\varnothing$ ndergaard, Department of Thoracic and Cardiovascular Surgery, and Professor Steen Olsen, University Institute of Pathology, Kommunehospitalet, Aarhus, Denmark for excellent laboratory facilities, and to Miss Mary Jo Jepsen and to Mrs. Karen Just for most conscientious and skillful technical assistance.
This study was supported by a grant from Statens Lægevidenskabelige Forskningsråd, Denmark.

\section{REFERENCES}

1. Samols, E., G. Marri, and V. Marks. 1966. Interrelationship of glucagon, insulin and glucose: the insulinogenic effect of glucagon. Diabetes. 15: 855.

2. Dupré, J., J. D. Curtis, R. H. Unger, R. W. Waddell, and J. C. Beck. 1969. Effects of secretin, pancreozymin, or gastrin on the response of the endocrine pancreas to administration of glucose or arginine in man. J. Clin. Invest. 48: 745.

3. Müller, W. A., G. R. Faloona, E. Aguilar-Paradar, and R. H. Unger. 1970. Abnormal alfa-cell function in diabetes. Response to carbohydrate and protein ingestion. N. Engl.J. Med. 283: 109.

4. Heding. Lise G. 1971. Radioimmunological determination of pancreatic and gut glucagon in plasma. Diabetologia. 7: 10 .

5. Unger, R. H., H. Ketterer, J. Dupré, and A. M. Eisentraut. 1967. The effects of secretin, pancreozymin, and gastrin on insulin and glucagon secretion in anesthetized dogs. J. Clin. Invest. 46: 630 .

6. Unger, R. H., A. Ohneda, I. Valverde, A. M. Eisentraut, and J. Exton. 1968. Characterization of the responses of circulating glucagon-like immunoreactivity to intraduodenal and intravenous administration of glucose. J. Clin. Invest. $47: 48$.

7. Ohneda, A., E. Parada, A. M. Eisentraut, and R. H. Unger. 1968. Characterization of response of circulating glucagon to intraduodenal and intravenous administration of amino acids. J. Clin. Invest. 47: 2305.

8. Unger, R. H., A. Ohneda, E. Aguilar-Parada, and A. M. Eisentraut. 1969. The role of aminogenic glucagon secretion in blood glucose homeostasis. J. Clin. Invest. 48: 810.

9. Ohneda, A., E. Aguilar-Paradar, A. M. Eisentraut, and R. H. Unger. 1969. Control of pancreatic glucagon secretion by glucose. Diabetes. $18: 1$.

10. Buchanan, K. D., J. E. Vance, K. Dinstl, and R. H. Williams. 1969. Effect of blood glucose on glucagon secretion in anaesthetized dogs. Diabetes. 18: 11.

11. Sokal, J. E., and E. Z. Ezdinli. 1967. Basal plasma glucagon levels of man. J. Clin. Invest. 46: 778.

12. Unger, R. H., E. Aguilar-Paradar, W. A. Müller, and A. M. Eisentraut. 1970. Studies of pancreatic alpha cell function in normal and diabetic subjects. J. Clin. Invest. 49: 837.

13. Iversen, J., and D. W. Miles. 1971. Evidence for a feedback inhibition of insulin on insulin secretion in the isolated, perfused canine pancreas. Diabetes. 20: 1 .

14. Ørskov, H. 1967. Wick-chromatography for the immunoassay of insulin. Scand. J. Clin. Lab. Invest. 20: 297.

15. Ørskov, H., H. Yde, and H. G. Thomsen. 1968. Wickchromatography for the rapid and reliable immunoassay of insulin, glucagon and growth hormone. Nature (London). 219: 193.

16. Hunter, W. M., and F. C. Greenwood. 1962. Preparation of iodine- ${ }^{181}$ labelled human growth hormone of high specific activity. Nature (London). 194: 495.

17. Samols, E., J. Tyler, C. Megyesi, and V. Marks. 1966. Immunochemical glucagon in human pancreas, gut, and plasma. Lancet. 2: 727.

18. Moody, A. J., J. Markussen, F. Sundby, C. Steenstrup, A. Schaich Freis, and G. S. Agerbak. 1970. The insulin 
releasing activities of extracts of pork intestine. Diabetologia. 6: 135.

19. Kaneto, A., Y. Mizuno, Y. Tasaka, and K. Kosaka. 1970. Stimulation of glucagon secretion by tetragastrin. Endocrinology. 86: 1175.

20. Grodsky, G. M., L. L. Bennett, D. Smith, and K. Nemechek. 1967. The effect of tolbutamide and glucose on the timed release of insulin from the isolated perfused pancreas. In tolbutamide after 10 years. W. J. H. Butterfield and W. von Westering, editors. Excerpta Medica Foundation, Amsterdam. 11.

21. Bennett, L. L., and G. M. Grodsky. 1967. Multiphasic aspects of insulin release after glucose and glucagon. In Diabetes. J. Östman, editor. Excerpta Medica Foundation, Amsterdam. Proceedings of the 6th Congress of the International Diabetes Federation.

22. Buchanan, K. D., J. E. Vance, and R. H. Williams. 1969. Insulin and glucagon release from isolated islets of Langerhans: effect of enteric factors. Diabetes. 18: 381.

23. Chesney, T. M., and J. G. Schofield. 1969. Studies on the secretion of pancreatic glucagon. Diabetes. 18: 627 .

24. Curry, D. L., L. L. Bennett, and G. M. Grodsky. 1968. Dynamics of insulin secretion by the perfused rat pancreas. Endocrinology. 83: 572 .

25. Porte, D. Jr., and A. A. Pupo. 1969. Insulin responses to glucose: evidence for a two pool system in man. J. Clin. Invest. 48: 2309.

26. Malette, L. E., J. H. Exton, and C. R. Park. 1969. Effects of glucagon on amino acid transport and utilization in the perfused rat liver. J. Biol. Chem. 244: 5724.
27. Chambers, J. W., R. H. Georg, and A. D. Bass. 1970. Effect of glucagon, cyclic $3^{\prime}, 5^{\prime}$-adenosine monophosphate and its dibutyryl derivative on amino acid uptake by the isolated perfused rat liver. Endocrinology. 87: 366.

28. Dupré, J., J. D. Curtis, R. W. Waddell, and J. C. Beck. 1968. Alimentary factors in the endocrine response to administration of arginine in man. Lancet. 2: 28 .

29. Grossman, M. I. 1970. Gastrin and its activities. Nature (London). 228: 1147.

30. Samols, E., G. Marri, and V. Marks. 1965. Promotion of insulin secretion by glucagon. Lancet. 2: 415.

31. Ketterer, H., A. M. Eisentraut, and R. H. Unger. 1967. Effect upon insulin secretion of physiologic doses of glucagon administered via the portal vein. Diabetes. 16: 283.

32. Turner, D. S., and N. McIntyre. 1966. Stimulation by glucagon of insulin release from rabbit pancreas in vitro. Lancet. 1: 351 .

33. Iversen, J. 1970. Secretion of immunoreactive insulin and glucagon from the isolated perfused canine pancreas following cyclic AMP, glucagon and theophylline. Proceedings of the 7th Congress of the International Diabetes Federation. Excerpta Medica Foundation. In press.

34. Curry, D. L. 1970. Glucagon potentiation of insulin secretion by the perfused rat pancreas. Diabetes. 19: 420 .

35. Fubgänger, R. D., K. Straub, R. Goberna, P. Jaros, K. E. Schröder, S. Raptis, and E. F. Pfeiffer. 1969. Primary secretion of insulin and secondary release of glucagon from the isolated perfused rat pancreas following stimulation with pancreozymin. Hormone Metab. Res. 1: 224. 